\title{
The silent reality: Racial discrimination in the Criminal Justice Process
}

\author{
by Lovell D. Fernandez
}

\section{Introduction}

During the course of 1980, the Centre for Applied Legal Studies at the University of the Witwatersrand in Johannesburg, South Africa, conducted a court-record study of 770 criminal cases dealt with by the Witwatersrand Local Division of the Supreme Court over a two year period, starting in January 1978. The aim was to find out the correlation between a chosen set of variables and the outcome of the trials. These were the variables: the age, race and sex of the accused; the race and sex of the victim; the charge; the plea; legal representation; bail; length of the trial; expert evidence; type of punishment and appeal.

The court-record method was chosen because court records serve to legitimize judicial decisions; secondly, documented details are an important means by which the magistrates court communicates with the Supreme Court, thus enabling it to reconstruct the case at hand.

The arbitrary choice of variables obviously limits the conclusiveness of the findings, but this does not, and should not, preclude one from pointing out significant correlations where they occur. This paper presents the major findings, which are analysed against the politico-legal fabric of the South African society.

\section{I. (a) General data}

Of the 770 accused $74,07 \%$ were black males; $2,34 \%$ black females; $11,41 \%$ white males; $0,78 \%$ white females; $1,43 \%$ Indian males; $9,86 \%$ coloured males and $0,13 \%$ coloured females. The most common charges were murder $(70,48 \%)$, robbery with aggravating circumstances $(9,62 \%)$ and robbery $(5,5 \%)$. Most of the accused, irrespectiveof race, were in the 20-30 year age group. Of the 766 victims, 57,34\% were black males; $13,14 \%$ white males; $8,91 \%$ coloured males; $7,33 \%$ white females; $1,52 \%$ Indian males; $0,96 \%$ coloured females and $0,14 \%$ Indian females. 


\section{Findings on Summary Trial Proceedings}

Proceedings before the magistrate were conducted mostly in Afrikaans. Interpreters were present in every case. In all cases no assessors were present. Most of the proceedings were in terms of section 115 of the Criminal Procedure Act ${ }^{1}$ which provides for the discretionary questioning, by the magistrate, of an accused at his trial. Thus, $89,7 \%$ of the accused pleaded 'not guilty'. In almost all cases where there was legal representation, a plea of 'not guilty' was entered. The incidence of the granting of the bail was significantly higher $(42,40 \%)$ for those who pleaded not guilty than for those who pleaded 'guilty' $(29,20 \%)$. Significant, too is that $39,31 \%$ of those who pleaded not guilty' at the summary trial were finally acquitted in the Supreme Court, as opposed to $6,00 \%$ who pleaded 'guilty`.

Only $22,42 \%$ of the accused were legally represented at the summary trial. The percentage of whites legally represented was 70,80\%; coloureds 29,60\%; Indians $28,60 \%$ and blacks $15,10 \%$. A striking correlation was found between the incidence of legal representation and the granting of bail: Where there was legal representation, bail was granted in $74,10 \%$ of the cases, as opposed to $42,74 \%$ of the cases where there was no legal representation.

No correlation was found between the sex of the accused and the granting of bail. Nor was there any correlation between the sex of the victim and the granting of bail. But a significant correlation emerged between the race of the accused and the incidence of the granting of bail. In the case of accused males, the granting of bail was highest for whites $(72,06 \%)$, followed by coloureds $(61,97 \%)$ and lowest for blacks $(44,24 \%)$. This discrepancy was noticeable, too, in the control for the race of the victim: Bail was refused in $66,67 \%$ of the cases where the victim was white, $31,48 \%$ of the cases where coloured and $48,44 \%$ where black. This discrepancy was further noticeable in the control for both the race and the sex of the victim.

Significant, too, is that the percentage of white males granted bail was much higher $(80,00 \%)$ than the percentage of black males granted bail where the victim was a white male $(34,62 \%)$. Also, the percentage of black males granted bail where the victim was a white female was much smaller $(34,62 \%)$ than was the case where white males were charged with crimes against black females $(80,00 \%)$. Where black males were charged with crimes against black females, bail was granted in $54,76 \%$ of the cases; and in the case of white males against white females it was $34,62 \%$.

It was also found that the average bail money fixed was much higher where the victim was white than where the victim was of another race.

In respect of the most common verdicts (murder with extenuating circumstances; assault with aggravating circumstances and culpable homicide) persons who were refused bail received much stiffer sentences than those granted bail. 
TABLE I: BAII_DY VICTIM

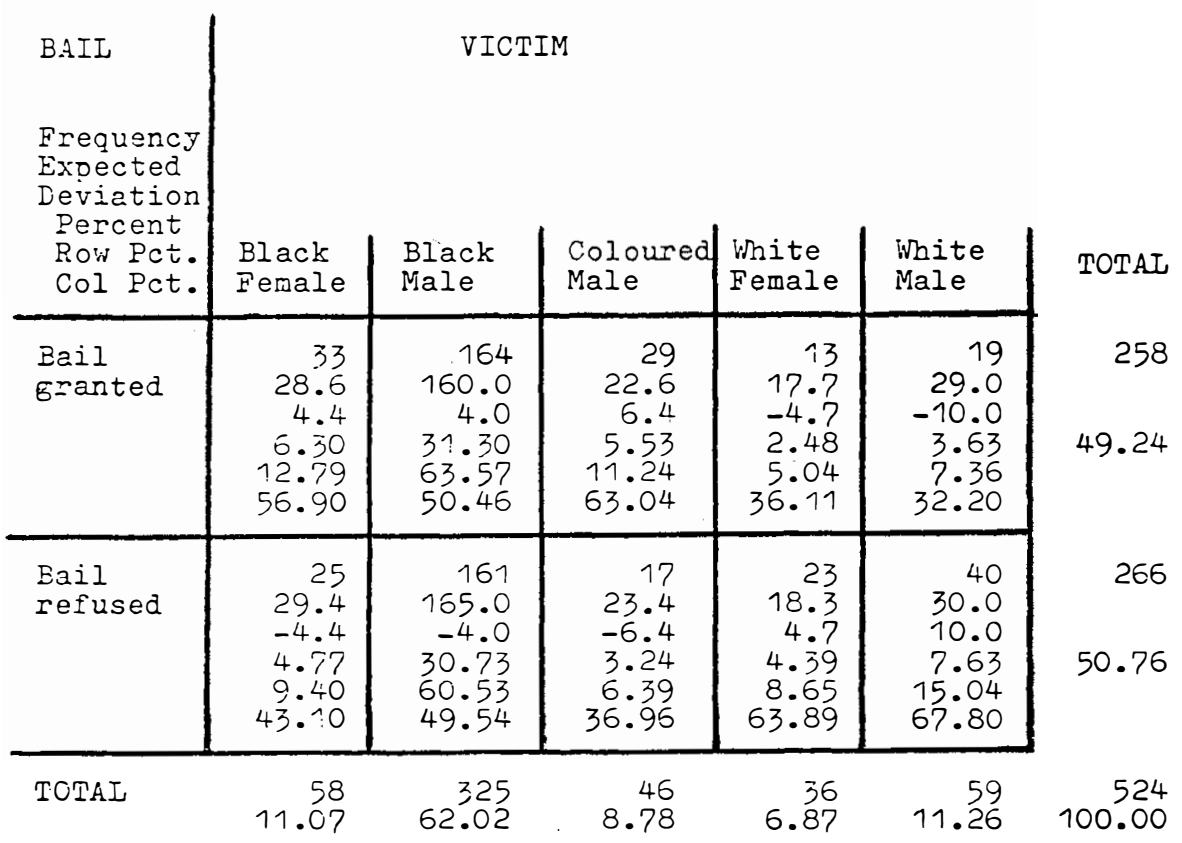

Statistics for 2-way tables

CHI-SQUARE $14.395 \quad D F=4$ SIGNIFICANCE $=0.0061$

How_to ré

Example 'Bail Granted' by 'Black Female'

First figure 33: no. of persons granted bail where victim vas a black female.

Second fig. 28.6: expected no. of persons granted bail where victim was a black female.

Third figure 4.4: deviation

Fourth fig. 6.30: percentage of all cases where victim was a black female and bail granted. ( 33 out of a total of 524)

Fifth fig. 12.79: percentage of persons granted bail where victim was a black female.

( 33 out of a total of 258)

Sixth fig. 56.90: percentage of cases where the victim was a black female and bail was granted.

33 out of a total of 58) 
The average period from the start of the summary trial to the end of the Supreme Court trial where the accused was refused bail and finally acquitted, was 243 days. Interesting is that no white person who was refused bail, was finally acquitted.

\section{Supreme Court Proceedings}

The study showed that $72,94 \%$ of the accused had pro Deo legal representation; $25,23 \%$ self retained counsel and 1,83\% were unassisted. Interpreters were present in all cases. Assessors were present only occasionally, though in $92,45 \%$ of the cases where the death penalty was imposed.

\section{III. (a) Expert Evidence}

In general, it was hard to ascertain the incidence of ordinary witnesses at the trial. However, the summary trial record showed that blacks rarely had witnesses to call. In several cases, where they did have witnesses, they did not know how to lecate them. Expert evidence was led in $5,78 \%$ of the cases and in only $1,89 \%$ of the cases where the death penalty was imposed. There was no significant difference in the use of expert evidence by pro Deo counsel as opposed to self retained counsel. But a significant discrepancy was noticed in the incidence of expert evidence where the control was for the race and sex of the accused: Expert evidence was led in $26,74 \%$ of the cases where the accused was a white male; $50,00 \%$ white female; $3,95 \%$ coloured male; $2,48 \%$ black male and in $2,56 \%$ of the cases where the accused was a black female.

\section{III. (b) Verdict}

No significant difference in the acquittal and the conviction rates between pro Deo and self retained counsul was established. Striking was the high conviction rate of white males $(84,09 \%)$ as opposed to black males $(62,92 \%)$. In the case of whites 74 were convicted as against an expected 57,3; and in the case of blacks it was 358 against an expected 370,3 (Significance $=0,0007$ ).

A significant discrepancy was found where the control was for the race and sex of the victim. As the table below shows, the conviction rate was much higher where the victim was white than where the victim was of another race.

\section{III. (c) Sentence}

The average length of prison sentences imposed was significantly shorter for females (19.80 months) than for males (46.28 months) (Significance $=0.0019)$. It was found, too, that accused with self retained counsel received less severe prison sentences on the 


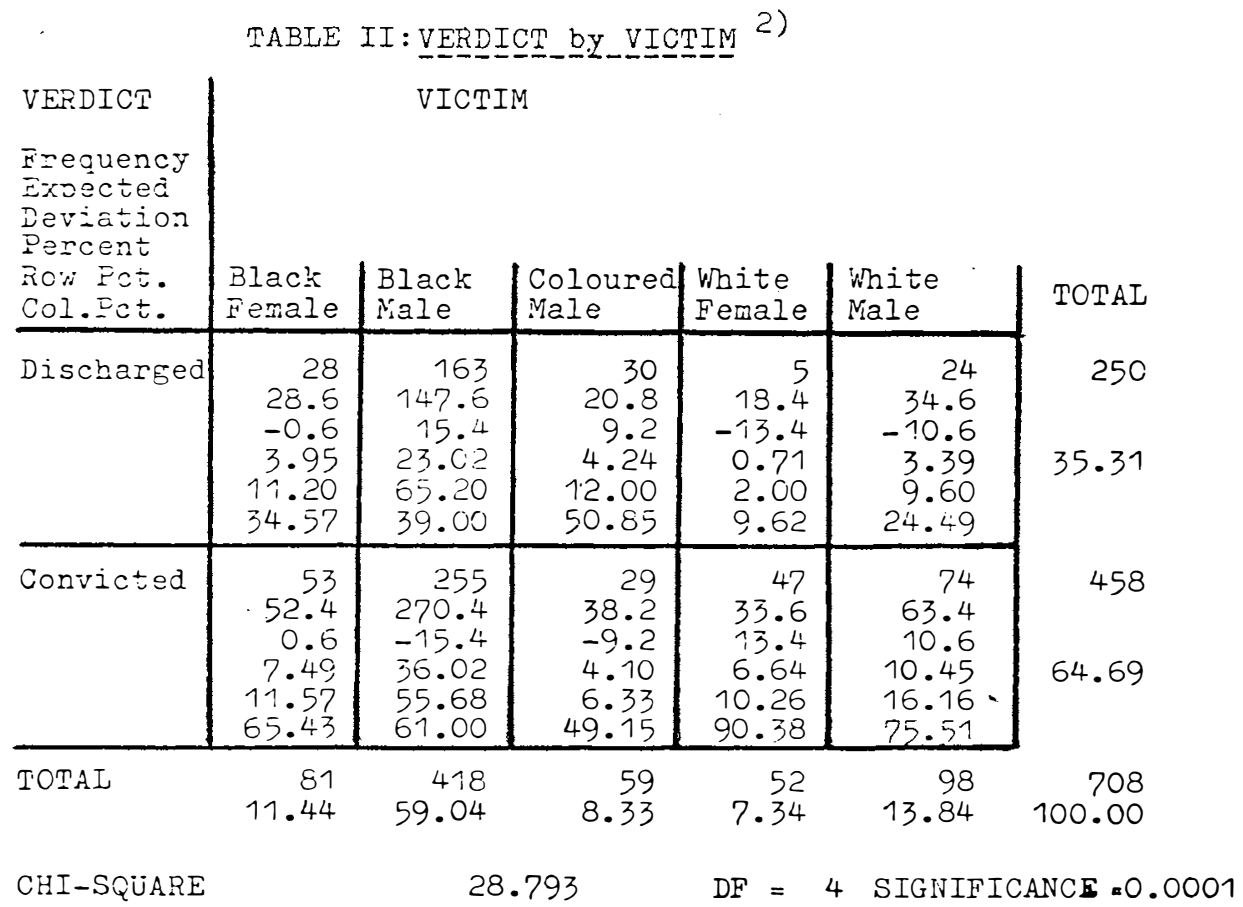

average than accused with pro Deo representation. In $44,05 \%$ of the cases where counsel was self retained, the accused was sentenced to imprisonment without the option of a fine; in the case of pro Deo counsel, it was 55,02\%. Also, where counsel was self retained, in $21,67 \%$ of the cases was the sentence wholly suspended, as compared to $11,24 \%$ of the cases where the defence was pro Deo. But again, and in so far as the sentence concerned "length of imprisonment", "portion suspended" and period over which suspended, it was found that in the common verdict, "guilty of culpable homicide", whites received less severe penalties than other races.

2 Explanation: example 'Discharged by 'Black Females.

First figure 28: number of persons discharged where victim was a black female.

Second fig. 28.6: expected number of persons discharged where victim was a black female.

Third fig. -0.6: deviation.

Fourth fig. 3.95: percentage of all cases where the victim was a black female and the accused discharged (28 of a total of 708).

Fifth fig. 11.20: percentage of accused discharged where victim was a black female (28 of a total of 250).

Sixth fig. 34.57: percentage of cases where the victim was a black female and accused discharged ( 28 of a total of 81 ).

The figure 81 is the total number of black female victims $(11.44 \%)$. 


\section{III. (d) Appeals}

A total of 108 applications for leave to appeal were recorded; 84 from blacks, 9 from coloureds, 2 from Indians and 13 from whites. In several cases applications were still pending. However, leave to appeal was granted to 11 blacks, 1 coloured and 6 whites.

\section{Discussion}

These findings show race to be an important variable in the dispensation of justice. This, it is submitted, is due to a combination of both subjective and objective determinable factors which can be traced back to the racially stratified nature of the South African society. The discussion below attempts to show how these factors influence the course and the outcome of the criminal justice process. As a starting point, the discussion focusses on the pre-trial, or system entry phase; more specifically, on the police in their relationship to the Apartheid society at large.

\section{IV. (a) The Police}

In South Africa the word 'policer suggests one thing to whites, and something else to blacks. Whites perceive police as genuine 'peace officers' who are there to protect peace-loving citizens by maintaining law and order. Indeed, this is the normal image of police in a civilized society. In South Africa, the positive perception of the police by whites is attributable to the fact that in their encounter with whites, police appear in standard gear and patrol in radio cars as is the case in Europe and in the United States, for example. Moreover, white metropolitan areas are patrolled mainly by white policemen with whom the white public can identify. It is not unusual for a white person to go up to a policeman on patrol to ask for some kind of assistance not related to a complaint. The defender role of the police is furthermore enhanced by such television (to which most whites have access) series, as Task Force, which portray the heroic role of the police in the routing of crime.

Blacks, on the other hand, have a contrasting view of police. This stems from the encounter situation: Police patrolling black residential areas appear in paramilitary outfit and are of ten accompanied by German wolf hounds; they appear in batallions and patrol in vans or huge 'pick up lorries, colloquially known amongst blacks as 'kwela! (jump in!). The sight of these caged vehicles which are normally filled with arrested people, is a terrifying experience, let alone for children on which it has an immense

psychological impact. Township mothers are able to bring to a sudden stop the wail of a child by merely pointing to a passing police vehicle or by threatening to call a policeman. Indeed, the negative and scarry image of the police is eloquently portrayed in the works of South Africa's leading black novelists and playwrights. 


\section{IV. (b) Discriminatory Treatment by Police}

In South Africa, blacks are subjected to more stringent police control than whites. This, however, is not a peculiarly South African phenomenon. Empirical studies elsewhere have shown that underprivileged social groups are more closely monitored by police than the privileged groups. ${ }^{3}$ This selective attention is, per se, discriminatory since it exposes one group to a higher risk of arrest and prosecution than another. In South Africa, the degree of discrimination is exacerbated by the fact that a great deal of police activity is directed at controlling behaviour in respect of which only persons with specific colour are subject. The fact that police activity is directed more at controlling black people for crime in respect of which there are no human victims and no human complainants, than at controlling white collar economic delinquency of the 'Muldergater variety, which harms the society at large and which is usually discovered only after damage is done, is discriminatory. According to the 1979 Survey of Race Relation In South Africa "pass laws resulted in approximately $5,8 \mathrm{~m}$ pass law prosecutions from 1965/66 - 1974/75. Imprisonment cost per year were estimated at $\mathrm{R} 18,7 \mathrm{~m}$, prosecutions $\mathrm{R} 1,7 \mathrm{~m}$, and pratrolling and policing $\mathrm{R} 11,5 \mathrm{~m}$. The time lost by people arrested amounted to $12,3 \mathrm{~m}$ productive man-hours, the equivalent of $\mathrm{R} 7,7 \mathrm{~m} \cdot$ " $^{4}$

The continued exposure to police surveillance results in many blacks being arrested for nothing. Between January 1978 and December 1979, the Minister of Police paid out R 74,975 to persons who had sued the police for wrongful arrest. ${ }^{5}$ No doubt, there are numerous blacks who, because of ignorance or fear, do not institute actions for wrongful arrest. The reason for such wrongful arrests stem from the agitation and nervousness in blacks in their encounter with police. Quinney rightly points, that "the definition 'criminal is less dependent on the infringement of specific criminal laws than on the manner of meeting between police and the suspect. The police officer asks himself whether the suspect exhibits any behaviourial symptoms which make a criminal behaviour likely. That is why the external appearance and conduct of the suspect play such a large role. $"{ }^{6}$

Also, complaints of pre-trial physical torture by police come almost exclusively from blacks. Between January 1978 and December 1979, a sum totalling R 431,335 was paid out to victims of police brutality. ${ }^{7}$ The reason for this kind of brutality is not clear. If it is

3 See, F. Sack, Neue Perspektiven in der Kriminologie in: R. König and F. Sack (ed.), Kriminalsoziologie, (Frankfurt, 1968) p. $431 \mathrm{ff}$.

4 At p. $390-391$.

5 Survey of Race Relations In South Africa, 1979, p. 108; Survey of Race Relations In South Africa, 1980, p. 230.

6 R. Quinney, Ansätze zu einer Soziologie des Strafrechts, in: K. Lüderssen (ed.), Abweichendes Verhalten II/I, (Frankfurt, 1976) p. 56; cf. I. Pillivian and S. Briar, Police Encounters with Juveniles, in: American Journal of Sociology, 1964, p. 210 ff.

7 Survey of Race Relations In South Africa, 1979, p. 108; Survey of Race Relations In South Africa, 1980, p. 230. 
to extract confessions in order to substantiate, or to ground a charge - which one suspects is the case - the Criminal Procedure Act of fers no relief. According to sec. 217 (1) the mere production of a confession made in writing before a magistrate, is admissible as evidence against the accused and is presumed to have been made freely and voluntarily unless the contrary can be proved. The onus is on the accused.

Black grievances from which white politicians are wont to shy away, are now being settled by police with paramilitary methods. The official designation of areas of social unrest as "operational areas", and of extra parliamentary opposition as "subversive elements", automatically arms the police with an unfettered discretion in their dealings with blacks. Because this type of discretion is not open to public scrutiny ${ }^{8}-$ evil though it is - the danger of it being employed indiscriminately is ever present. The increased militarization of the police in the wake of the Soweto school unrest, has already blurred the line between police action and military operation. Evidence of this is the statement by the Commissioner of Police, who warned that police would "shoot to kill ". ${ }^{9}$ The result is that the cherished division of powers between the executive and the judiciary, has been reduced to an absurdity. Furthermore, the principles of state security legislation are implemented with the help of procedural regulations which de facto delegate to the security police the power to decide who shall stand trial, if at all. The pre-trial interrogation of detainees by police under the drastic process is not subject to judicial control. The result is that where the trial does take place, the accused, their lawyers and the prosecutors are given very unequal roles, much to the detriment of the accused.

\section{IV. (c) The Trial Phase - The Climate of Inequality}

For a trial to be fair, the accused should be accorded the right to substantial parity with the prosecution. This means he should be given an effective chance to challenge any and all evidence produced by the prosecution and to present evidence in defense. In broad juristic terms, this is known as the principle of "equality of arms". In legal systems with the inquisitorial procedure, this principle cannot apply literally during the pre-trial stage, given the different roles of accuser and accused. But this principle has been accepted as a critical component of a fair trial. In its report on the applications of Ofner and Hopfinger against Austria, the European Commission of Human Rights was of the opinion that "what is generally called the requality of arms', that is the procedural equality of the accused with the public prosecutor, is an inherent element of a fair trial. «10

South Africa espouses the adversary system of procedure in which both the pre-trial and trial procedures are characterized by an open and equal confrontation between the

8 See, Section 3 of Act 16 of 1956 as amended by section 10 of Act 102 of 1972

9 The Star, 18 June 1980.

10 No. 524/59 and 617/59, Yearbook 6, p. 681, at 696. 
accuser and the accused. ${ }^{11}$ Furthermore the postulate of requality before the law' has been laid down in our case law. In Zgili v McLeod, Lord De Villiers cogently stated: "It is the primary function of the court to protect the rights of individuals which may be infringed, and it makes no difference whether the individual occupies a palace or a hut. "12 Unfortunately, this principle exists only on paper, for in practice it has been twisted every which way to accommodate the elastic definitions of "state security" and "national interest ". ${ }^{13}$

If we accept the import of both the De Villiers postulate and the principle of requality of arms', namely that any accused should be afforded a symmetrical chance with the prosecution to avail himself effectively of all procedural safeguards accorded him by law, we should ask ourselves whether South African standards of justice measure up to this definition.

The submission is that in South Africa standards of justice are, consciously or unconsciously, applied according to the colour of the skin. The reason for saying this is predicated upon a realistic perception of a criminal trial, not as being a gray machinery of justice propelled by its own mechanical chain of events, but as social interactive process with an eminently human component, in which the various, parties, with different motives, participate in proportion to their resources. In order to avail himself effectively of the equal opportunity safeguard, the accused has to mobilize all cognitive, verbal and interactive resources at his disposal, in order to secure an outcome most favourable to himself.

In South Africa the bulk of the accused in criminal trials are blacks with limited resource capacities. They are, for the most part, indigent black persons with little or no educational background and with very limited communication skills. They come into court bearing the stigma of being second-class citizens with no political rights, and all the negative biographic details associated with that status. Most of them, as seen from the court-study findings, are without legal representation. The other principal participants in the court room - the magistrate and the prosecutor - are white - a colour the accused associates with might and with his own helplessness. This feeling is accentuated by the fact that proceedings in the magistrates' courts are usually conducted in Afrikaans, a language he associates with the police. Indeed, the accused sees himself as having no legal rights. ${ }^{14}$ The cumulative, negative psychological impact of these factors impair his communication ability - his bearing, his mood, his tone. Besides, communication is through an interpreter who, as was noted in a close-in study of the Commissioners' Courts in Johannesburg, can prejudice the case of the accused. ${ }^{15}$ The plight of the black accused, is described by Mc Millan:

11 J. Dugard, Human Rights and the South African Legal Order (Princeton, 1978), p. 267.

12 (1904) 21 S.C. p. 150 at 152.

13 See, E. Devenish, Equality before the law, in: De Rebus, April 1979, p. $189 \mathrm{ff}$.

14 M. Slabbert, Justice for all?, (Institute of Criminology, University of Cape Town, 1981) p. 41.

15 Sunday Express, 14 September 1980. 
$\mathrm{He}$ is deficient in, if not totally ignorant of, the language of the courts' proceedings; even if he understands more than fragments from an interpreter, the atmosphere of a law court must add to his natural embarrassment in the presence of masters who are still more conscious of their own superiority to this ragged, unwashed, stammering mortal. This very feeling of superiority is a sore tax on the white man's impartiality and sense of justice in deciding for a coloured person against a white man. ${ }^{16}$

Another prerequisite for a fair trial is that the adjudicating officer must be impartial. He should not make up his mind before either side has presented its case. However, in the process of making up his mind, or of arriving at the material truth, he is guided by his own conscience. ${ }^{17}$ In South Africa the magistrates - who adjudicate over the bulk of the cases - are civil servants; so, too, are the prosecutors and the investigating police officers. They all serve the State and "have a firmly rooted bias in favour of the State inevitably produced by a working life dedicated to the service of its interests and implementation of its policies. ${ }^{18}$ On this point Jackson comments:

The very nature of their training and experience makes the magistrates lean towards the prosecution. This is particularly evident in young magistrates fresh from promotion as prosecutors. The promotion and salary of magistrates are controlled by merit committees from Pretoria. These committees travel to all parts of the country examining cases completed by each magistrate, the number of convictions and acquittals and his general demeanour (or his allegiance to the party line in his interpretation of the law). Those magistrates able to dispense justicer very quickly are noted for promotion. ${ }^{19}$

This coalition of state interests introduces an important variable in the judicial process where the interests of a black accused are weighed against those of a state dedicated to the preservation of white supremacy. According to Blumberg, the privity of interests within the court organization "exert a higher claim than the stated ideological goals of 'due process of law', and are often inconsistent with them. ${ }^{\prime 20}$ The fact that South African magistrates are enjoined from making adverse comments on police from the Bench, ${ }^{21}$ violates a fundamental procedural safeguard afforded the accused: publicity. ${ }^{22}$ One of the most unedifying features of our criminal justice system has been the stepped

16 W. M. Mac Millan, The cape colour question, (London, 1927) p. 159.

17 S. Mikinovic and W. Stangl, Strafprozeß und Herrschaft, (Luchterhand, 1978) p. 29 and footnote 36 at p. 45.

18 The Hon. Mr. Justice J. Didcott, Memorandum to the Hoexter Commission, reported in Rand Daily Mail. 14 October 1980.

19 J. D. Jackson, Justice in South Africa, (Penguin Books, New York, 1980) p. 23-24.

20 A. S. Blumberg, The Practise of Law as Confidence Game, in: V. Aubert (ed.) Sociology of Law, (Hammondsworth, 1967) p. 321 at 322.

21 The Hon. Mr. Justice J. Didcott, op. cit.

22 Section 152 of the Criminal Procedure Act, No. 51 of 1977. 
up, unilateral appointment of National Party supporters to the Bench. Professor John Dugard points out that at least fifty per cent of the judiciary could broadly be described as supporters of the National Party Government. ${ }^{23}$ That these elevations to the Bench are not always founded on merit, is envinced in part by the statements of two South African Ministers of Justice reminding certain political appointees that they should not imagine they were appointed on merit. ${ }^{24}$ The fact these appointments are made in total disregard of the amply qualified and distinguished advocates known for their antiracist views, evinces the government's inexorable intent to convert the Supreme Court into an organ of justification. This becomes transparent when seen against the discretionary powers delegated to the judge in interpreting vaguely worded political crimes enacted to crush black political opposition to the government. On this point Torstein Eckhoff observes:

Judicial policy-making can in some instances be conceived as a service rendered the political authorities. It is of ten convenient for a legislator to use broad and unspecified language in the statutory provisions and leave to the courts to work out in detail the ways in which social interests should be promoted. But this presupposes that legislators and judges by and large share the same values. The situation is quite different if political and judicial authorities pursue incompatible policies. In that case judicial policymaking will not be a service to the political authorities but will on the contrary hinder them in carrying out their own objectives. ${ }^{25}$

\section{Conclusion}

This discussion has merely attempted to portray some of the features of the criminal justice order against which the findings of the court study should be read.

One should not shy away from the fact that the South African criminal justice system is racially discriminatory. Professor Van Niekerk, who was known for his candid views on the workings of the criminal justice system, once said: "There has to this day been a conspiracy of silence, co-perpetuated to some extent by all of us (or most of us) on the problem of racial inequality within and before the law. ${ }^{26}$ The South African government is, indeed, a passmaster at the art of diversionary debate and semantic hair-solitting. Slogans are consciously mistaken for solutions: The official appellation accorded the black man evolved from 'Kaffir' to 'native', to 'Bantu', to 'non-white', to 'African', to

23 Dugard, op. cit., p. 284.

24 Referred to by Dugard, op. cit., p. 285.

25 The relationship between judicial and political branches of government, in: Sociology of the Judicial Process, Vol. IV, (Opladen, 1976), p. 14 at p. 18.

26 Address to southern Africa law conference at Sun City, Bophuthatswana, reported in The Star, 13 August 1980. 
Itemporary sojourner', and today he is called a 'foreigner'. This verbal evolution has, however, not been accompanied by any improvement in the legal status of the blacks; instead, it has merely served to camouflage legislative curtailment of their fundamental rights. Similarly, one should not be fooled into believing that the oft-bandied law and order ' is synonymous to 'peace; nor that legality، is a substitute for 'justicer.

Mencken once said: "The most costly of all follies is to believe passionately in the palpably not true. ${ }^{27}$ It is submitted that the legal profession can lance the boil of self deception by addressing more openly and more critically the racial irritants within the criminal justice administration. No matter how much one tries to smother open discussion, one will never efface the scar the criminal justice system had left on nearly every adult black. It is true to say that the criminal process had, indeed, become the staple gauntlet that blacks are born to run. Out of this common dehumanizing experience has grown an intense hatred for the Apartheid political order, a hatred which manifests itself in the waves of public violence that sweep the face of the country from day to day. To cling tenaciously to legalism and legalistic thinking at this very hour, or to spend a great deal of the time "shoveling smoke", ${ }^{28}$ as Oliver Wendell Holmes (Jr.) would put it, one is directly creating the ingredients for an Aristotelian tragedy.

Now, what is it that the legal profession should do?

Ideologically, it should move away from the neutral and formal strictures of the Begriffsjurisprudenz to a valueorientated Interessenjurisprudenz. In the words of Professor Dugard: "The plea here is not for any particular theory of natural law, but simply for the rejection of the strict positivist approach to the role of values in the legal process. $"{ }^{29}$ A positivistic legal science has, after all, to exercise self criticism. As a starting point, the illusion that the law functions neutrally and apolitically should be dispelled. Mere formal equality alone, in a racially classed society, is not the sole component of justice.

Concretely, the legal profession as a whole should agitate more vigorously for the restoration to each and every South African citizen of his or her full complement of classical and social human rights as contained in international instruments; and to agitate that these be ensconsed in a Bill of Rights. This could be done by giving effective material and vocal support to those people and organizations dedicated to this goal. In so far as it concerns the criminal justice process the legal profession should:

- campaign for the decriminilization of all acts and ideas which have neither victims nor complainants or where the victim is the offender himself. The legislature should be pressurized unrelentingly into eliminating the social conditions which render one segment of the population more victimogenous than the other;

29 Dugard, op. cit., p. 398-399. 
- strive to maintain the full independence of the legal profession as a whole and to repulse any moves by the executive arm of government to extend its suzerainty over the judiciary. Lawyers must support vigorously the demand that judges and magistrates be appointed on merit by an independent council and not by an ideologically inspired Minister of Justice;

- seek actively an alternative to the money-bail system which as it presently obtains, discriminates against indigent persons;

- campaign for removal of official discretionary powers in respect of the granting of legal aid; and to substitute same with the automatic granting of legal aid to any indigent accused facing the possibility of a prison sentence;

- must insist on the presence of assessors at every trial where the accused faces a prison sentence. The discretionary powers that judges and the Minister of Justice have with regard to the presence of assessors should be taken away. Lawyers must join the call made in 1838 by the Attorney General of New South Wales, Bannister, ${ }^{30}$ that responsible black assessors must be present where the accused is black.

The discretionary powers of the police in crisis management should be open to full public scrutiny. The police should stop seeing the blacks as potential troublemakers. Furthermore, the police should be incorporated into an overall plan of criminal policy which aims ot the rehabilitation of the offender. As a starting point they should develop a different self-awareness - that of police as a sort of social hygiene.

Lastly, black attorneys should not shy away from the chance to occupy the office of public prosecutor, for it is here that one can achieve infinitely more justice in one case than in years of private practice.

It is submitted that if these ideas are implemented, one could well say that the South African system of criminal process, though not perfect, is, at least, humane. 


\title{
The Silent Reality: Racial Discrimination in the Criminal Justice Process
}

\author{
By Lovell D. Fernandez
}

The study shows race to be an important variable influencing the outcome of South African criminal trials. The racial discriminatory laws and the way they are implemented ensure that the black population in particular remains in constant contact with the criminal justice system. The court-record study shows that black persons charged with capital offences are denied a chance to defend themselves effectively: either because they are subject to the whims of low-ranking administration officials. The latter is especially manifest in the realm of state-endangering crimes where the Executive enjoys considerable latitude in its dealings with detainees and accused persons. An obligation rests on the legal profession to address itself earnestly to the inequities in the criminal justice system. The plea is for a humane justice. Lawyers should resist attempts to bring the judiciary under the control if the Executive. Furthermore, an urgent need exists to expand the ambit of criminal legal aid.

\section{The Sahara Conflict and the Crisis of the Organization of African Unity}

\section{By Jürgen Taeger}

The Organization of African Unity (OAU) which has the most individual members of any regional international organization is now experiencing the greatest test of its strength and effectiveness in its 20 -year history.

In 1975, through the tripartite Treaty of Madrid, Spain transferred possession of the colony to Morocco and Mauritania. This action was in itself a breach of the existing Decolonization Rules. Since then the population of the Western Sahara has been struggling to achieve self-determination. In 1976, following the withdrawal of the colonial power Spain, a new state, the Saharan Arab Democratic Rebuplic (SADR), was founded.

After the signing of a peace treaty between the SADR and Mauritania, Morocco demanded possession of the entire Sahara and proceeded to occupy the so-called wuseful triangle", an area in the northwest of the Sahara which is very rich in raw materials. The present economic situation in Morocco is catastrophic; the Moroccan king, Hassan II, is able to continue his war against the Saharan Independence Movement, the POLISARIO Front, only with massive economic and military support from the United States.

For years, Hassan II has successfully employed delaying tactics to frustrate the attempts of international organizations, especially of the OAU, to find a diplomatic solution to the conflict. Despite these tactics, Hassan II was unable to prevent admission of the SADR as the 52 nd member of the OAU. The monarch and sympathetic African heads of state are now threatening to boycott the OAU. Hassan's efforts did prevent a referen- 